\title{
日本に利当労衝衛生の発展
}

\author{
一一本産業衛生協会 30 週年記念号飞よせて—
}

睴 峻 義 等*

\section{I 日本における労衝衛生の誕生前後の時代}

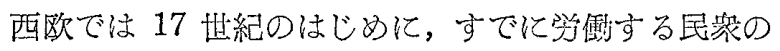
ための科学と技術がうまれた。学働者の病気をなおし，

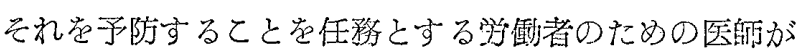
あらわれたのだ。「私核宮殿の中に住む貴族たちのため に医業总行なうのではない。壁にまみれ，汗みどらにな って働いている市井の労微者てそ, 私の医療の内容であ る」と宣官して「工芸人の病気について」というささや かな書物をかいた。关の内容は始汃ら終りまで, 働ら く労働者の病気の症状, その原因と治療とについやされ ている。ての著速はまさに画期的なものである。社会的 進歩の新らたなる段階に応して，新らたなる動向を示唆 したものとして，まさに歷史に戦やいている。それは17 世紀の始めに出版された, イタリーのラマッチニーの書 物で, 労衝衛生の一つの声典であり, ラマッチニーてそ は医学の社会的適用の新らしい道をひらいたという意味 で尊敬さるべき，われわれの同志であり，また先達の人

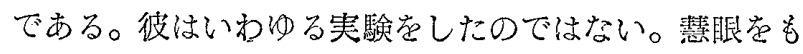

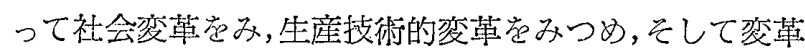
のなかから㭁てってくる人間の新らたな健康障害の性賀 をみつめていたのだ。彼の著述をみると，彼の眼にみ， 人間にふれて, 具体的につかみ得る限り, この新らしい 病状を分析し, 分類し, 抄判して, そてに職業别のその時代に新らしく発生した，新らしい生産技術の実践 者としての学働者一工芸家の病気党丹念傠録すると いう方法をとっている。

少し時代がおくれるが,18世紀の終りになると,ウィ一 ンですばらしい大著があらわれている。にれはヨハン・ ペーター・フランク（ウィーン大学医学部教授）の「医 学的警察制度」という表題をもっているが，てれは封建 社会がまさに資本主義社会に移行しつつあった時代に生 きた寚識な医学者——臨床医学の大家に，その㭙代の学 濑階級一一貧困な民象の状態がどうとられ，また彼がそ

* 本協会名誉会員
の社会に生きて，な沈なさねばならぬかな，われわれ に書きのてした大著であるという点で，注目すべき文献 だと思う。そのなかで，彼は貧团という社会現象，貧困

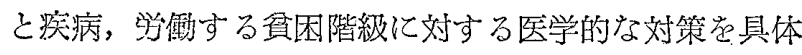
的に詳細に述べている。彼の述べているとてるは，今日 でも，なお充分に指頨佂值をっているものである。と くに彼が大学教授として，教育者であり，4,000人にの ぼる欧川各国からの医学生に講義をしたという事実任， その時代の社会がいか社会問題，労働問題に対する医 学的な新らしい見解を要求していたかる推定させるに充 分だと思う。

てのようにして, 西欧社会の前進にくらべると, 日本 は二, 三百年おくれて, 学㗢医学, 学働簿生の仕事に出 発した。てれはもちろん德川期における敛国政治によっ て, 日本か新らしい生産技術の採用によっての社会的生 産の発達に非賞なおくれ范とったということに原因があ る。そして日本は明治時代の変革の少し以前まで，その 久しい封建政治体制とその体制下の学铺の㵠取と大衆の 貧困, 社会発展への動力としての生産技術の停頓に原因 するものである。

昭治の初期から中期, 後期にかけての日本の社会は， いす的る富国強兵を政治の目標とした時代である。新ら しい生産技術は移入せられた。社会的生産はグングン向 上した。だがその半面, 亚業はおき去りにされ, 農業生 産は工業生産力の発展にともなうず，農民は躬乏し，譨 村人口は貧困に陌った。貧因な農村汃ら都会へ，工業へ と人口が颔収されて，都市人口ほ次第に增大していった が，资本僋先の社会情勢の下では，富の分配は不洋均と なり, 都市民, 工業学儗者の貧困, 大群の貧困学働者を

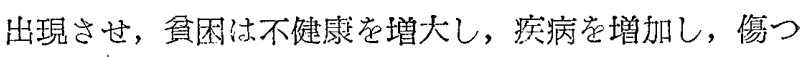
き，病むとと多き都市人口は再び㸵村に還元されるとい う状態がくりかえされていく間に，農村人口と都市工場 労働者群のなかに, 結核の感染, 蒙姃が著るしく目に立 つようになるに及んで，日本の政界は大きな，しかも悲 惨な事実に眼を覆うことが不可能になった。

まず内務省に大正のはじめに保健衛生調查会が成立し 
た。乙の調查会は全国の代表的農村人口について，その 健康状態を精密に調查し保健対策をら.ち立てるという使 命を考っていた。この新らしい仕事仙当然の效果赏あげ た。その結果として，農村の結核对策，寄生虫病対策が

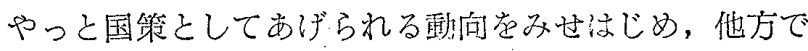
は健康保险制度の研究力晸府の手ではじめられた。しか

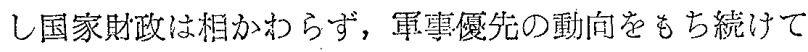
いたのだから，零態は到底，国民の踝健問題についての 保健衛生調查会の結論を具体化しようとする方向へ蛙動 かなかったてとは当然である。

かようにして，ようやく発展しようとしていた日本の 資本主義経済も，兑の土台がまだ定まるないうちに，す でに重大染危機に立っていたのである。また日本の震村 は国民が日本の工業化住眼をうばわれ，その経済的発展 にのみ，日本の将来の繁栄を期待し，農村と農民とをお ろそかにしたがために，すなわち，工業偏電の政策のた

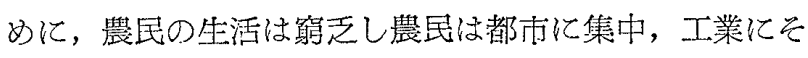

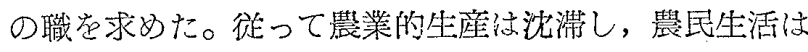
ひどく窮乏した。全国の都市の工業からストライキが続 発し，貧笨した農民は米騒動芷おてして，兑れが全国的 に伝播するに至って，国をあげて物情騒然たるるのがあ った。

この時代である。日本人のなか，とくに法学, 経济学, 社会政策の専閒家の間から，一つの思想的芽生えがあら われた。それは重要な芽生えである。社会問題と学㗢問 題との正しい解決は科学的研究に基づく，科学的見解と 科学的手段による以外に方法はない，というととであっ た。端的にいうと，之れは社会科学的知見に基づくべき であるという主張である。学働問題という近代社会の発 達のはかから生み出された新らしい問題は, 近代社会科 学の方法によって解决していてうとする要望であるとい おう。

日本で学衝者の衛生問題が論議され出したのは，大正 の初期だといってよいだろう。大正 5 年にいたって， 学働者の貧因と量民の䆣乏とが社会問題として，大きく クローズアップされ出した。日本の連命结社会問題, 貧 その防止にかかっているといら認識が生まれて来たてと は蜆大なととである。

大正 5 年に政府の要人や財界の有力者によって, 財 団法人（労資）協調会が発足した。たが上に述べたよう に, 社会科学への熱心な期待がかけられていた当時の情 勢にもかかわらず，政府や財界の人々は，社会科学とい う言葉を使うととを極度におそれた。社会科学は当時な お政府の弾圧の下にあったのだ。とのような情勢の下で
は，学働問題，社会問題の解決のために創立された協調 会が，問題の本筫を紏明するととによって，資本主義経 済の発展のうちに生み出された重大なヒズミ一病幣と しての学働力の旦期消耗や篎㗢階級の唯一の資本として の健策状態の俧機に対して，乙れを解決しょうという本 筋をえらび進むしとをさけて，ただ㤵蒙と埦調という立。

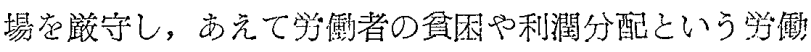
者解放の根本的な問題の打開に邁進するための勇気に欠 けていたてとは当然である。

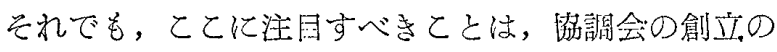
当初には，その機棈のなかに，産業能率の調查研究部門

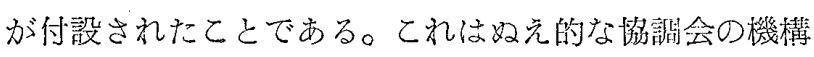
に人間一学例力というものについて，関心をおてさせ る一つの需要な仕事であったと私は考えている。ての能 率部門を担当したのは，当洔，谁㠺的な青年心理学者，上 野陽一氏一後には産業能率研究所を独自に創立した。 しかし，ての研究所は奉験的な研究というよりも，むし ろ経営者, 資本家存能率心理学上の諸原則に従って, 㤵 蒙し，指導するととが，只の主たる仕事であった）であ った。しかし游調会依ての能率心理学的研究には充分な 関心蛋示さず，これに上野君がよほど努力したのだと思 われるが，上野君の意志はついに滓成されずに終った。

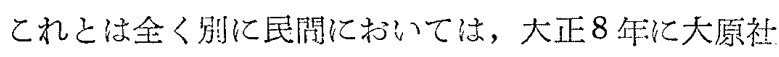
会閵題研究所か溌足した(大阪)。乞の組織は経济学，法 学, 社会学等の研究者—ひとつかみにいうと, 社会科 学矿究グループに並んで, 影働生理学の研究者が学㗢者 の疲労問題の研究を目的として, その研究緗織の檴成要 素となっていた。ての生理学部門缺担当したのが不肖私

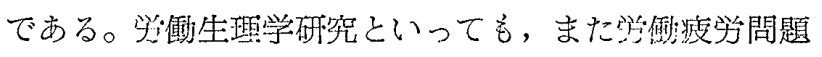
の研究といっても, それは実に複雑な生理的現象であ りまた他面，きわめて錯楼した社会的関連のなかの問 題である。しかも私に浬せられた大任弱は，試験的に人

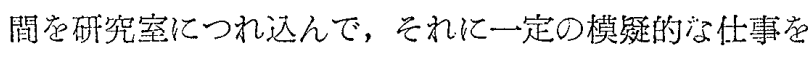
させ，その労㖶負担の下における生体の反応在観察する というような要求ではなく, 現に資本主義的経営内部 で, 現実の学働, 罢境条件のなかで働らく, 学働現場の

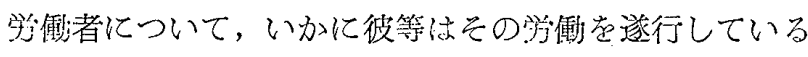

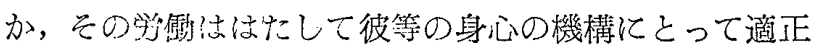
であり得るのか, 彼の外的環境之彼等の内部的㻴境とが はたしてよく調整するてとによって，学墈の遂行が行な われているのか, 彼等のおかれている経济的, 社会的諸 要件ははたして彼等の生命ある機搆の全体の諷和的な運 行と発展とをよく保持せしめうるに足るものであるのか ぞうか，てれ究明するととは容易のととで法ない。当 
時，一简の青年学究であった私のよく為し得るとてろで स安い。

このころ，私付扵でに東京警視庁に10カ月䦎正式に官 吏一一保健衛生技版という珍引しい名の職にういてい た。（大原社会問題研究所入所前）そてで私は東京の極 貧生活者（日収 5 銭〜10銭）の群のなかに居住して，つ

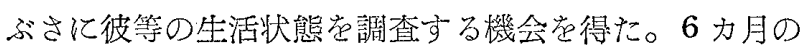
貧民生活の期間は私は貧国というものがどんなねおえろ しい社会悪であるか存しみじみ見とどけさせてくれた。 これはたしかに資本主義社会のおそるべき落し子である ととなさまざまの現実によってみとどけ得たと思う。て の研究生活はその後の私の学究生活に，いろいろの意味 で大きな影響军与えた。

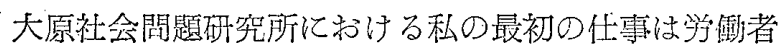

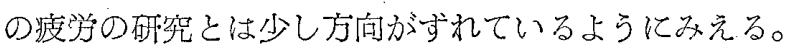
研究室もない。生瑟紫的な方法の採用は研究の基地とい らよりなものがなくては笑施できない。当時，私は大原

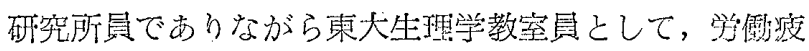

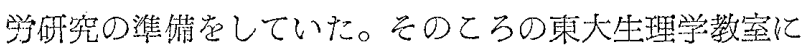
は人間といら高級な生命について実験するための便益に 众けていた。生物の電気現象がそてでは中心㹎題であっ たから，祍経纎維の伝導過程の追求，筋繊維の活動にお ける蠜現嗮過程の追求といった純正广生体機權の基本的 間題に関する同㒄研究者の熱情と努才には大い敬意を 表していたが，私に課せられている閏題の然筫はあまり にも複雑であり，一定の定められた条件下に行われるこ れらの精密綮正な科学的方法とは, 學極の目的がー一つで

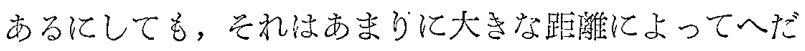
てられていた。

私の任務に対して私の選んだ方法仙刺戟に対する反応 時閻の測定であった。それにはその些㭙の状態からいっ て，ヒップのクロノスコープ崖使用ずるほかに手がな い。生理学教室の機械棚の隅に拥してまれているクロノ スコープ亟取り出して,いろいろの視覚的, 聴覚的, 知覚 的刺㦸に対する反応時間の变化や身体的，心的角荷によ ってその変化をあらゆる角度から検討する仕事がはじま った゚。ての実験证簡单であるが, しかし, 反応といら現 象，それ在㭙閻の長短によって計測するというととは，

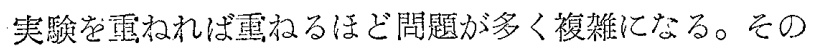
反応時間の変化のなかから, 望遍的子現象走つかみ出

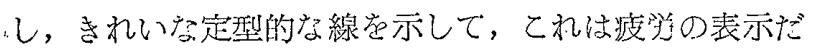
という大担な絽論老出すとと難かしく，かつ不自然で すらある。しかし，私はこの最初の実験から，一つの重 要な結論に達した。それは他にしめすため, 等僛者の疼
脬の防此のために役立つ結論ではない。要約すると，て の奉験は私に生命体の高級な生体の現象，クロノスコー プにあらわれる1000 分の数秒という反応㭙聞のなかに は生体のあらゆる生命過程の変化が想見され，內部環境 と外的環境との調整の過程がおとりつづけている，とい

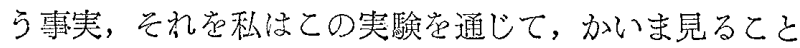

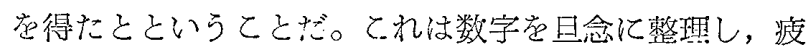

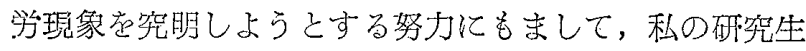
活に大きな答与走与えれと思う。

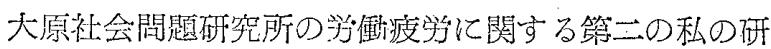
究は，「乳児死亡の社会的原因に罢する研究」である。 てれは大原研究所が新らしい研究所のなかに，等衔疲学

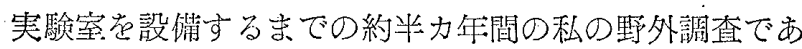

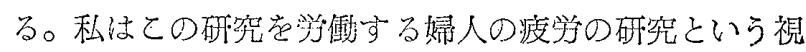
野のなかにとらえ炕つもである。私はての研究ではじ

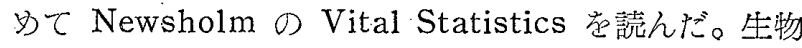

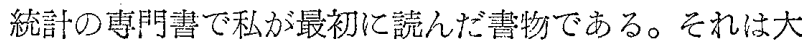
正 9 年のととだ。日本活当時との方面の專門舅はなかっ た。丸善の新刊舅のなかにてれ荧発見して，むさぼるよ うに読んで抄訳した。これは韭常に役に立った。私の視 野学ひろぬてくれた。

乳㫕死亡の社会的源因の研究の対象况当時の織布家内 工業の中心地，八王子である。汽車が八王子に近づく と、ザーツと䧻音がきとえてくる。何百台という手織の シャットルの活動が需なりあった騒音である。そとには 出来高払いの織在工業か溌達していて, 町全体の家々に 1 台，2台の手織が方方り，主婦や娘たらが家計の維持の ために，㡺間蛅もちろん，夜業点して働らいたのだ。乳

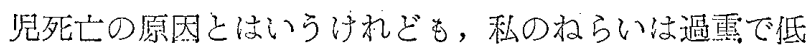

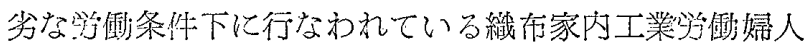
の弤娠，出産，保育という，人間の生殖，增殖過程の追 及であり，従って，そ礼は生殖能，保育能 (授乳能) に

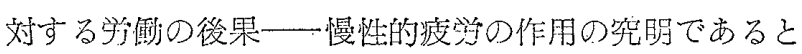
いう立場に立った研究であったの点。しかし，私法この

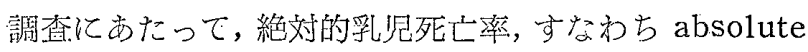
infant mortality-rate の方法を採用した。ある 1 力年

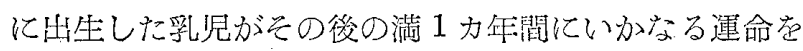
たどるか正礁につ加むととだ。ての方法活手数がかか

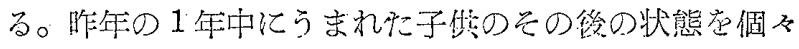

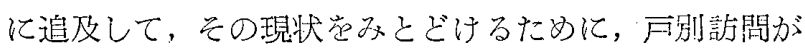
金町にわたって，2 カ月半の㭙日が損された。ある日䔎

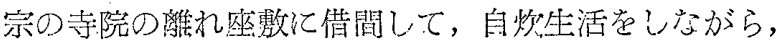

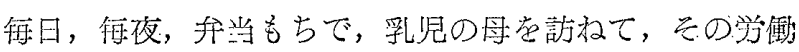
と保商つ現状存観察，記録した。しれ证中小企業一一家 


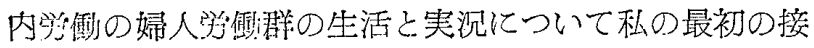

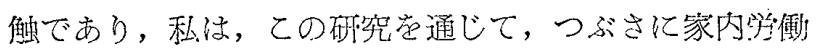

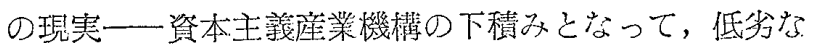

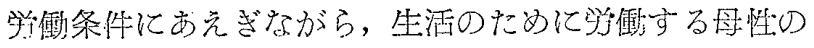

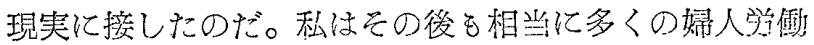

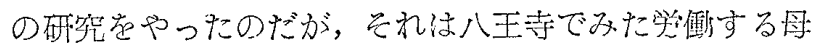
性の現実が私堂導いたのだ。

とのとろ, 救世軍のブースが，資本主䍩発展の絶媔に あったイギリス社会の貝困について論した彼の名哮

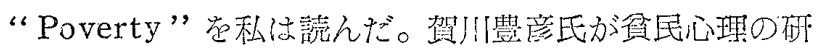

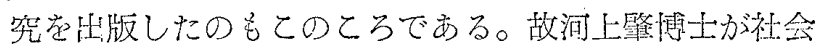
問題研究によって，資本主義社会に新焦発刺たる批判と 警告と荍発したととも，生ふしい訊憶の一つである。

また私はドイツのミユンステルベルグの Grundriß der Industrialpsychologie から，いろいろの教示花

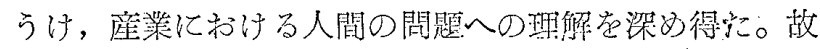

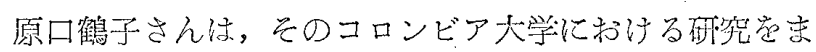
とめて「心的作業と疲等の研究」老出版した。乙れはア メリカのプラグマティズムに立った有用な研究の集䅡で

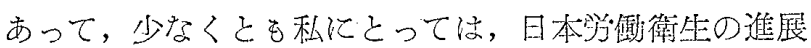
の一道程であると信ずる。

このてろ，欧州大陸の先進産業国の先頭に立っていた ベルギーの地位にも注目さるべきものがある。国土はせ

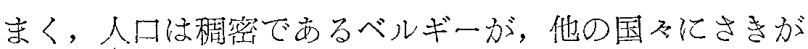

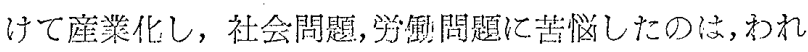

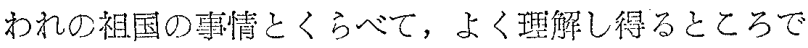
ある。ベルギーの第一の富豪であったソルベー(Solvey) がブラッセルにソルベー研究所堂創立したの㳘，20世紀 の頭初のことである。そてでは社会科学の研究がはじま

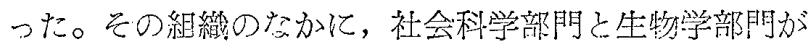
設けられた。それには社会病理学の研昆という目標がう ち出された。社会病理学といっても，それ出当時の医学

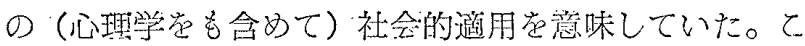
の研究所にいたポーランド出身の Dr. Josefa Iotekyo 女史によって“The Science of Labour and its Organisation" (London 1919) というモ!グラフが出版さ れ，それが 1921 年に丸善に輸入されて，私の手許に大 った。てれは等焦者の疲癹についての新らしい見解はな いもない。私はただ，そのモノグラフに与壳られた名に 一種の䅐しさ在感心た。るちろん，ての時代にはすでに Arbeits wissenschaft といらドイツ語岕使引れてい たのだから，以实の創見と防い光ない。

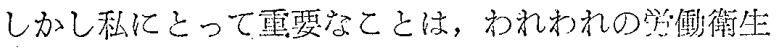

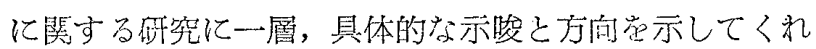

たものは、アメリカのコロンビア大学生整学のリー (F. Lee) 教授の Human Machine and Industrial Efficiency(1916年)である。ての害は私の生理学教室の 先輩かつ同僚灾る, 故宮崎北大教授がアメり力に留学 し, ニニーヨークに着くと同時に，乙礼觉発胃して，故 永井先生あてに送っできものである。故永开先生注す

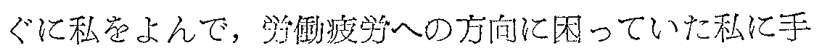
渡されだ。てれ惊すばらしい名著だっだ。複鹤で鍇楱し

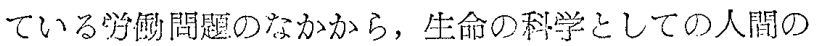
利学の主題たるい゙き諸雅項が，実端的に摘出され，膨 大な数に上る資糊方，周到な教慮と批判に立って，該

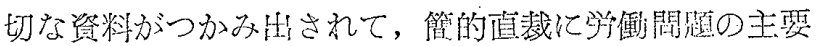
项件についての生理学的見解が眼快に諭破されている。

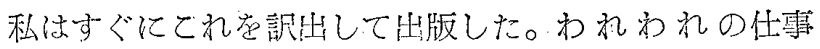
は，てのり一の萿述のふかに，彼によって提出された閏

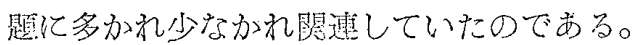

1910 年から 20 年の間に，アメリカに淁じまって，欧

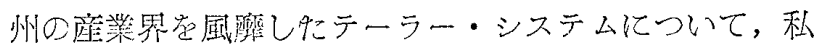

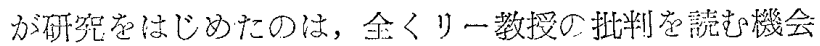

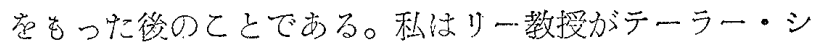

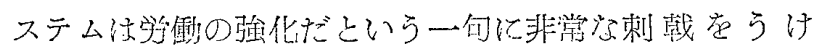

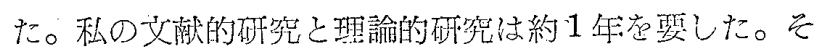

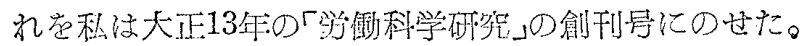

今日でも日本の应業経営认は，いまだ根強く, テーラ 一・システムが根岩張っている。それは，ての理諭が生

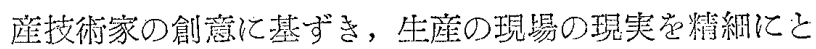
らえるとてろから出発しているとの理的にっって，生産 現場を握っている人洼の関心售めるからである。その 後, テーラー・システムも, その理論の内部から，いく たの変革, 進歩が热され続けてきて，経営管理，生産管 理，資材管理，人閒集可の管理，マス・コミュニケーショ ンなどに発展をこげたが，てれらの学衔問题処琵の科学 的手段の進步発達のな汃㧒，今日もな拆然として生 産幽向上という命題の下に，生産幽の過度の向上手段に

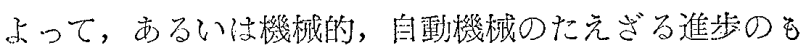
たらすところの人間性の制压によって一一れれ資本主 義的追的競争々科学续術の採用の当然の緗果である—

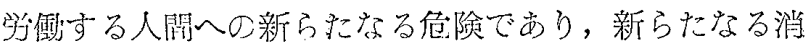

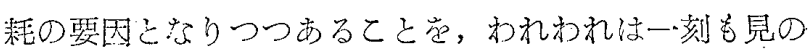

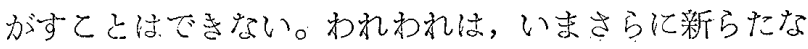

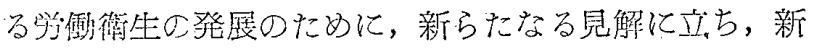

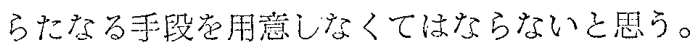

生産性の向上への，たえまない社会的要請に答えるた わに，創造されつつある生産技術の発展の幽賢と動问と 
にわれわれは常に注意を急ってはならない。われわれ

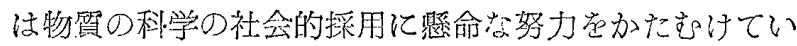
る生産技術家群の媸力に対して尊敬と近親感をもってい る。だが，われわれはただ彼等の妢力による生産技術の 採用によつて，生産性向上の成果に敗惑され，いたずら

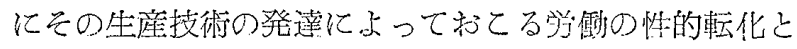
学働環境諸条件の変化に調子学あわせ，云れに同調する ための労微衛生の建設と活動とに終始しては灾引ない。 われわれの務めはてのような生産技術の一一生産性向上 技術への人間性范基礎とする批判であるべきであろう。 そしててのような技術の猢判的精神，批判的科学精神し そは，まさしく技術なして真に技術たらしめる，寸なわ ち生産技術の進步がただちに人間を救い人闑总福祉にみ ちびくための，社会進橴の動团としての洒值を発探し得 しめるための黄要な要件であると思う。私路過去におけ るテーラー・システムのわが産業社会への導入の歴吏的 過程をいまてて回顧して，ての新引た烦る技術段階にお

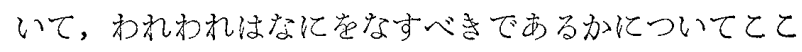
に一言した次第である。

資本家経営の否定は工場觉つぶすととに等しい。われ

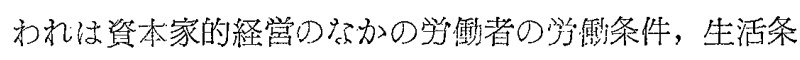
件について，气てで自由に資料学集內，学㗢環境が士

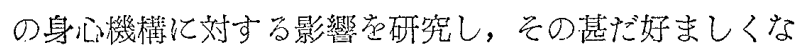
い不吉な資料党さ光も，大原氏から与光られた。乙れは あの详識な，独立の精神に立つ，故大原氏だからできた ことで，到底，他の資本家のよくなし得るとしろではな

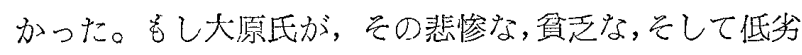
な学㗢条件の下の女工の生活已学㫦条件との資料の公表 荧担んでいたら，われわれの研究の発展はの资み得なか ったに相違ない。しかもてれが日本の片田舎の食影で, 私莡はじめ,わずか数人の関䋆者の協力によってはじま ったのである。ガスもない，水道导ない，科学研究の土 台としてあらゆる社会的便宜に欠けていた。ての荒地の なかで，婦人影働の研究がはじまったのだ。私からいう の䒹誠にオコがましい話であるが。笑にすばらしい歴史 的な事実であるではないか。政府当局者はこの研究所の 成立を徵迎しなかったし，事实，私蝶いつも警察力の監 視のながあのったといってよい。

かくて，てのすばらしいが，しかし困難な仕事索発端 として，わが日本に等衔衛生という学間と，その活動と か誕生し，元して発展萑遂げたのである。そして，てれて

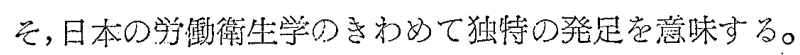

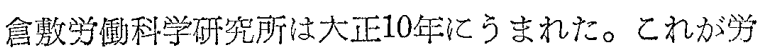
働の街生についての日本最初の科学的研究機関であり，
ての科学の誕生である。しかし，てに以前に労働者の 衛生の研究が全然少かったのではない。たと光ば，大正 3 年でろには，陸軍で栄養学の研究をしていた，故稻葉 良太郎軍医により「工業衛生学」という青物が出た。る ちろん, 軍の直轄工場管理の必要から出版されたに相違 ない。气の队容位ドイツ書の秏案であるのは，ての時代 として当然であろう。また大正のはじものてうには, 故

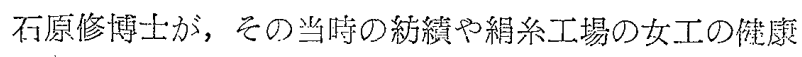
状態一体電の測定（これ法石原氏がやったのではな

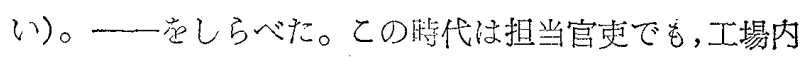
へはいるてと学，経営者は断して敨さなかったのだ。徐 って石原氏の譋査は尃ら警官の職棈による強制的調查で あったのだから，今日からみると，气の調查方法なども 非常に粗雑なものであった。しかも不原氏ほての資料を

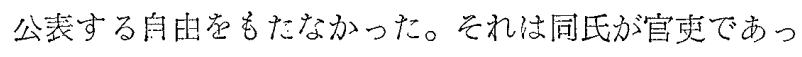
たし，官宁の調查は上官の許可なしに公表できなかっ た。しかし，ての上うな資料の觜無の時代であったので ての石原氏の資料は，その後，故川上繁博士がその藷

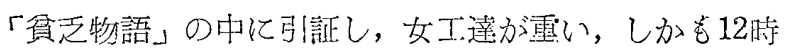

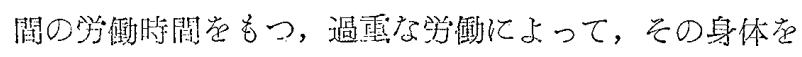

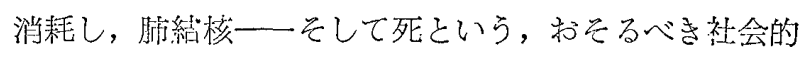

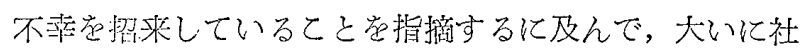
会問題，学微問題の発展を刺激するに役立ったのだ。

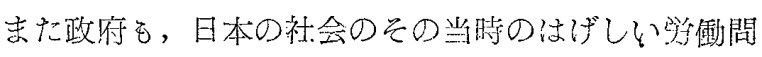

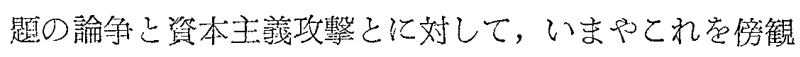
するととが許されなくなり，座業を担当する当時の官庁

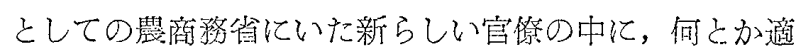
切な強力な手をうって, 解決対籍党講ずる还要痛感し ていた人洼かいた。当時の新進官僚の 1 人としての, 故 四条工務呞長など，てれらの人及が主唱者となって，ま

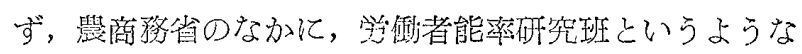
ものができた。能率研究というのは，一種のカムフラー

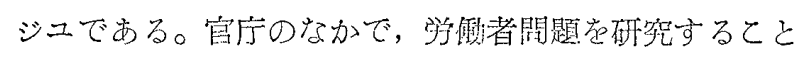
法何事ぞというような非難がはげしくおてって, 強才な 反撃にあう危除があったので, 能率砸究などといわざる を得なかったのだ。この時代は餈本万能の㭙代だった。 政治家と餈本家が緊密にとり組んで, 日本に賞国强兵政 策少行ない続けられていたのである。また，か小らな力 ムフラージユをしなくては，予算存出し々うもなかっ た。だから，体のよい能率研究と称して，第衔者の街生 の研究がはじわられたのである。この研究に参画したの が, 故小泉陸金中将である。乙の成縝仿, しかし, 公表 されていない。小泉さんは論文や報告存あまり毒かない

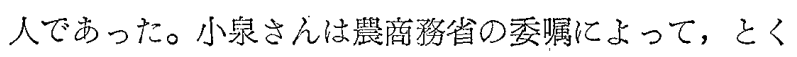


に四条局長という進歩的官僚の支援のもとに，ガス代謝 方法によって，学傎者のエネルギー代謝をやられていた らしい。陸軍省か蕽商務省に一というょりも，小泉と いう医学者と四条という社会政策の主脳者が拹力して， ての仕事がはじ竞ったと理解してもよい。（小泉氏蛙 演論文のなかに，ての資料蒚散発的につかっている)

\section{II 日本の学衝衛生の特色}

とてろが倉教学研を創設するに際して, 私はこの研究 所の組織機構のなが，人間の身体学としての生理学と ならんで, 人間の精神の学としての心翼学部門を扔くて との必要痛感した。

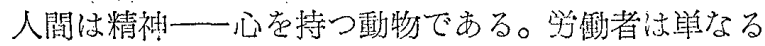
エネルギーの主体ではなく一感情, 意識, 理性をも。 ている。われわれが，人間の学働の研究を行なうとする ならば，単に身体一一生理学的锶点からだけではなく，

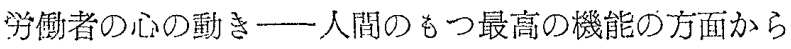

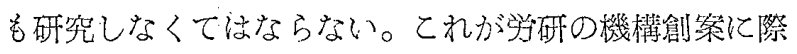
しての, 私の信念であった。气の時代の生理学は, 内分 泌腺の研究がすで亿辉やかしい成果党あげて，心身一 ことに感情の発露や，従ってはとれ之密接に関㳀してい る意志や行動の発起万至致抑制の機原について，医学者 の関心が昂まっていたし，フエルボルン教授は脳の機棈 のなかに，心的過程な追求しようと試みていた。また， パウロフ教授は气の輝やかしい条件反射の実験的展開に よって, 機權に即して, 心的活動の究明に進んでいた洔 である。

学研にはかくて，最初から，身体と心との関連におい

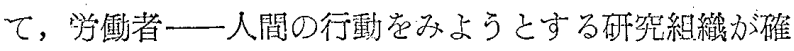
立されていたのである。ドイツでは，1920年にルブネル の主張によって, 学働生理学の研究空がベルリンに生ま れた。てれは倉數紡績工場で，われわれが研究をはじわ た年と同年のととである。とのドイツの研究所は，正 磪には Kaiser-Wilhelm's Institut für Arbeitsphysiologie (現在の Max Plank Institut für Arbeitsphisiologie) である。乙の研究所には学锄生理学, 学衔栄養学, 学㗢衛生学並びに統計学の研究空がおが ている。

私がての研究所学訪ねたのは 1922 年であるが，元の 時は創始者で,ドイツ寒駼衛生学の宿老である M. Rubner が所長であり，その下にアッレル教授(A. Atzler) がいた。私法アッレル教授に，私の研究所で仙心理学部 閶をおいているが，なぜあなたの研究所には人間の精

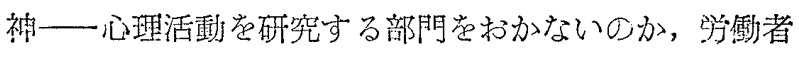

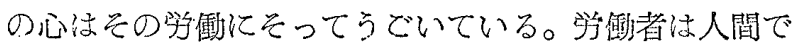
ある。生理学的対象である之同㭙に, 人間は心的活動の 対象であるなどと話したととがある。その後, 第 2 回目 に私方渡欧したとき(1934) に，ベルリン郊外 Dahlem に新らたに建てられていたての研究所在再び游れてみる と，心理学部門方併置さ礼ていたの党みた。しかし，ソ 璉では今日もなお，パヴロイズムの原則の上に箄として 立脚していて, 西欧の観念的心理学の要素营多分にもっ ている心理学の採用を欲しないのは当然である。だが不 必要なのは钼念諭であって，理学ではない。沁的現象 はそれ自体として研究に值する電要な人間性の特貿で亦 る。心的現象老客観的な方法でとらえようとする心理学 的研究は斥けらるべきで注ないと思う。

それはともかくとして，大正 10 年に学确が創設され て, 日本は学働簿生の本格的な研究へスタートしたので ある。てのスタートでわれわ礼がつかまえた間題住何で

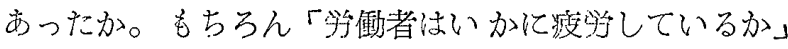
であった。当㭙织学䔬者の就業の最低年命は 12 才であ った。12才で義務教育を終了するのだから，てれ是最低 年令として，关れ以上で就学を部可するといら立前であ る。12才とい光ば今日の小学校 6 年生である。京るで少 年少女だ。乙の幼ない少年少女が，その当㭙の日本産業 の中核として大いに外貨をかせぎ，世界とくにイギりス

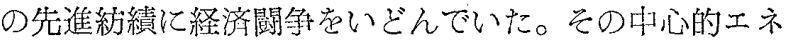
ルギーであったのであるから，实に今日教えてみると， 陰惨で，警獏すべきてこである。日本の人口の 7 割を占 める農民の貧困が，ての幼弱者在紀績にかり立て，賃金か せぎをさせて，やっと生活を維持し得たのだ。だから女

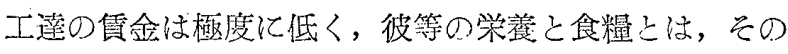
学衝の必要㦼さえるみたし得なかったてとはいうまでも ない。当洔は義務教育往 12 才で終了するととになって いたから，紡績に集められる女工達の年令は 12 才以上 であるべきはずであるが，貧乏な壊家は 12 才の義務教 育の終了なることができない。教科書も買えない，学 用品艺買光ないほど貧乏なのげ。げから，12才と称しな がら，実は 9 才，10才，11才というような，戔務教育の 未終了者が紀績工場认貨金を求乡て集まってきた。義務 教育を棒にふらせて，貧農の子女老賃金のため傎らか せ，家計を支える必要があったのである。少灰に家計の 手伝をさせて，貧農を助けているのだといら見方をする のが然然だと考えられていたのだ。しかし，笑際におい ては，紡績女工となるととは，少女の心身の発育と热康

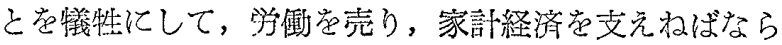


ないという，政治的貧困と政治性の反社会性とを意味し たのである。

われわれが学研創立の最初の研究対象としてとりあげ た「疲等」そいう問題は，今日の「疲学」問題とはその

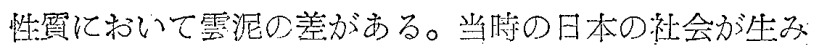
出した幼少年路側者の疲学の問題であったのだ。問題は

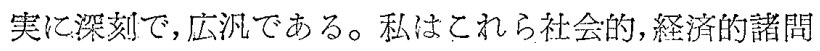
題のなか加投げ出されている不幸子幼若者一女工の疲

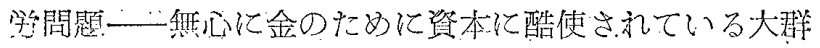

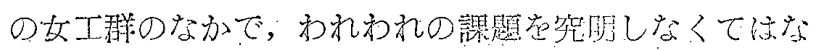
ら高以立場仙自ら好んで，進み大ったのだ。

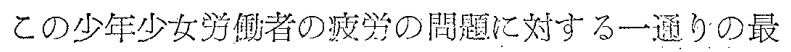

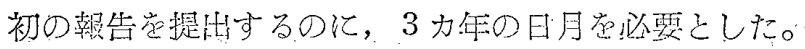
それはわれわれの同志，研究者がての研究の結果がまき おてすであらうと考光られた零大な社会的作用在予見し て，きわすて慎雷な態度觉とったからである。われわれ

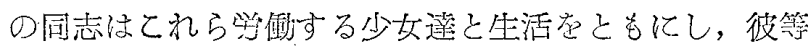
とともに職場の中で研究に娺力した。光して，そこに 提出された坏告は，乙の問題の基本的解沃のための最も 適切で，かつ公正な内容学もっていた。てのなが盛ら れている專実は，1)産業の最低年令は 16 才にひきあげ らるべきであるとと，2）女子一てとに青年女子の学 働時閔注短縮せらるべきとと（当時 12 洔間を 8 㭙間に） 3）女子の深夜業は即㭙撤廃せ弓るべきとと，4）12㬨間 2交代制度の全面的改廃等であった。てのようふ結諭柱 当時の日本紡續の資本主蓖経営の利潤中心主義の根本学 えぐるもので，紟續資本経営の心藏部にアイクチ岂つき つけるにも等しいものであった。（潭峻論丈「義弱教育 の延長江関する生理学的諭扰参照)

事実，乙の諭文は日本朝野の与諭䘮随起することに有 力に作用した。䀡和 4 年には，明治末期に議会荧通過し た工場法の中の女子深夜業廢止の条文が実施となり，12 時間 2 交代制は廃正され，女子の深夜業はわれわれの眼

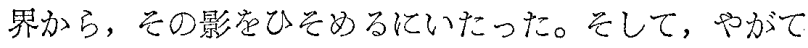
はさらに煡康保険法分㑼和 2 年に笑施されるに至った。 われわれの疲爫の研究は，乞の最初の輝やか儿い成功范 おさめ得たというべきであろう。

風知のとおり，日本人の身体の発育，従って只の精神 の発迲统，大体 9-12才（思春期前期）と13-16才（思 春期後期)の 2 期の患春期発育期它経て，17--18才の完 成期范迎え，20才でほぼ完成の域に達するととが，私達 の研究で確珰された。これはわれわれの研究成果の雷要 な事実である。乙の事実に立つと，日本民族の身心の発

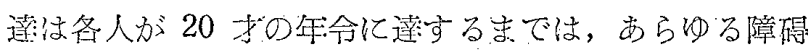

赏排除して，年令 20 才までの間の，ての身心の発達㞾 完成するよう護られなくてはならない。それは国民資留

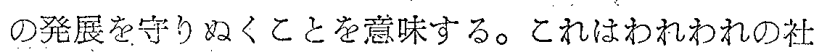
会の義務であり；国家が個人一国民に対する最高の義 務である。そうだとすれば，当時の最低12才という就業 年命の法令，並びに現行の 15 才といら最低就紫年令の 法令は，国民の身心発育老守り欢くという社会的，国家

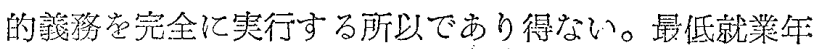

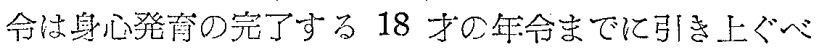

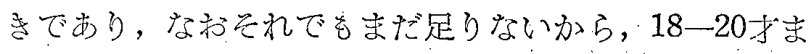
ではたと光，家庭の事情や社会経済の諸条件によって，

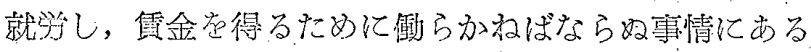

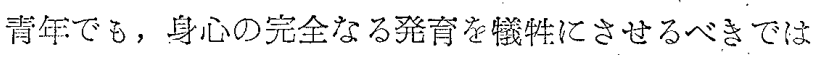
ない。従って 18-20 才までの青年住特別な法令索設け て, 半学; 半学—半日学路, 半日修学の方法の採用に よって：專ら只の至高の義務としての身心の発育を完了 せしぬ，もって国民資留の完了に資すべきである，と主張 した。(との主張は最近のソ建邦の教育制度の改鞾内容 にほぼ相似である）ての結諭は，あまり大案の注目を引 かなかったし，また多くの人々には「また腪峪の理想主

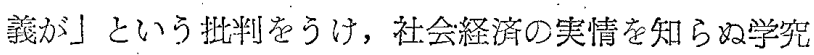
諭だと片づけられたのであるが，ての事実に基いて私の 発裴した「義㢷教育年令延辱」についてなる一諭文は， 教育界に大きな反響をもたらす結果となった。そしてて れがその後の学㗢就業の最低年令を 15 才とするとと, 義務教育年限の 14 才までの延長という国論に有力な資 料となったとと老，私々一学究として，非常に光栄を感 じ, 顿び落得て, さらに学徒としての努力に邁進するて そに力范与えられたと思う。

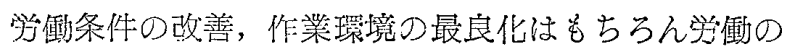
生産幽の问上という，つね汸わわれの目標としている 問題にこっては，䨌要な要件であるに相違ない。学働者 の心射の能力の水準の向上のための,より高い適切な 「教育」によっての学隉者の教養の向上てそは，一㬝に 根本的なととである。なぜならば，高い教育によっての 学働人格の向上，育成とそ，すなわち，篎働者の教育に よっての人格的能力の発展てそ, 労譈者解放の最良の手 段である。学墈条件の改善, 作業条件, 環境条件の最良

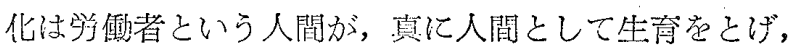
立派な人間——他たかな思考力と判断力と老旨つ有能な 行動力ある人間になるととによってのみ実現可能であ る。こてで学衝者ははじめて, 自らの能力によって, 自

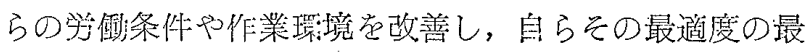
高能力を発揮して篎衝する人間となるととができる。籍 
極するところ, 学働者の教育—学衔者の教養の向上, その人間狌の完成の手段としての教骨てそ，自明な人間 への学働者の解放と学慟条件の最良化の最善の途である というのが，私の科学的立埸であり，私の信念である。

工場法の改正，健鬇保除法の実施方行なわれたのは， 丁度, 私の「義務教育年限延甚の必要」という諭文が公 表された時期である。前者は眧和 4 年，後者结昭和 2 年 である。私逢の研究所は紡績工場の中にあった。私は研

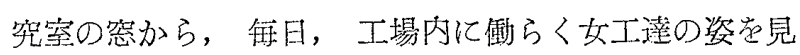
ていた。彼女等の煩结，樑夜業の撤廃，学澌封間の短縮 とともに，元の䋨果としてみるみるらちに，私の眼の前

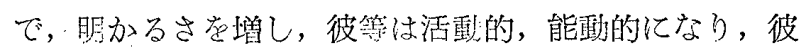

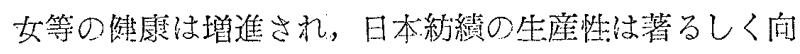
上した。このようなすばらしい維果は，少なくと虽現実

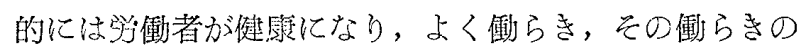
なかでよく考え，よく行動する人閐になったからだ。だ が，てのような生産性问上が并たらされたのは，ただ首

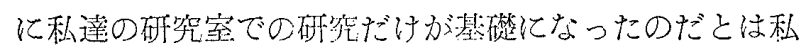
导考光ない。

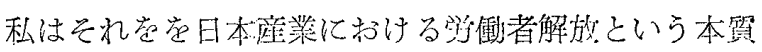
的な問題に関連していると信じている。当時の女工珪や 学㗢渾動者にとって结，学働者の現実にはまだまだ多く の不满, 尔楩があったに相違ないが, 少なくとも, 私の

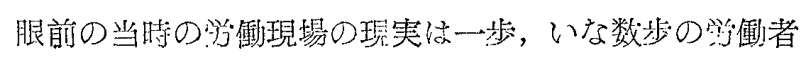
解放への方向への躍進であったからである。私はての当 時に, 私が見得た現实から，学働者の解放——学㗢者

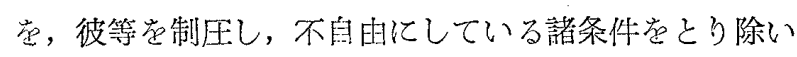

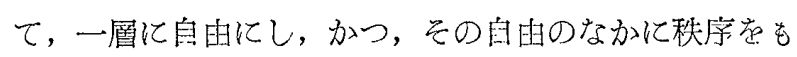
たらすととによって，学㗢の生産性は必らず向上するも のだというととを確認するにいたったととは，私の学究 生活のふかでの最も大き収獲であったと思う。

\section{III 労働衛生の普及と徹底は医学と 生産技術との協同の広場で—}

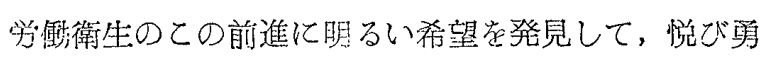
んだ私は，学働科学研究所内での学究的な研究だけ，い わば象牙の塔の中だけで, 学墈者の解放, 只の学働能の 增進という大事業は決して実現し得るものではないとい うととをしみじみと感じていた。われわれ蛙ひるくわが

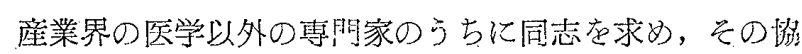
力と㺟同とによって，ての新事態に対処して，学働者の

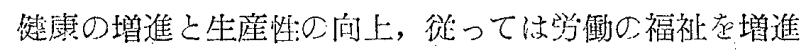
するととの急隆であるてと思っだ。

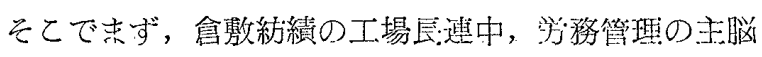

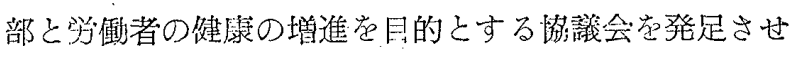

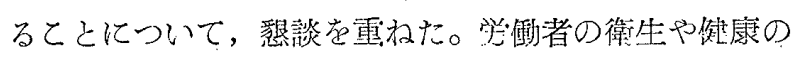
增進の問題はさしあたり, 日本全国の工場に在勤する工 場医師の問題であると，産業圈内の当局者も考えてお り，医師もまたもちろん，そう照いてんでいた。とて

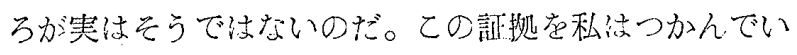
たのだ。

それは学㣫者の健康はまずなとをさしおいても学働

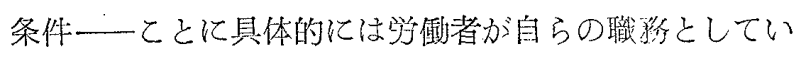

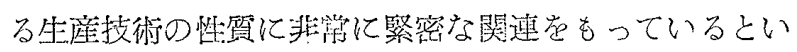
う事実の碓䜅であっだ。端的にいうと，生産の续術が人

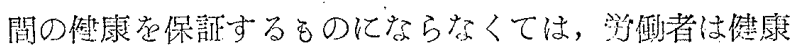

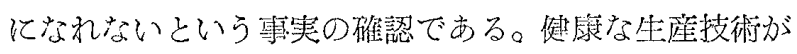

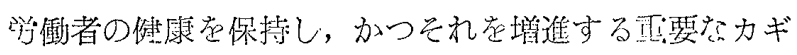
なのだ。をれを私济えの当時の女子等働の夜業撤廃の時 そみとどけたのだ。過去 30〜40年にわたって，1日就 業 12 洔間，昼夜 2 交代, 24 時間連続操業在繶けてきた

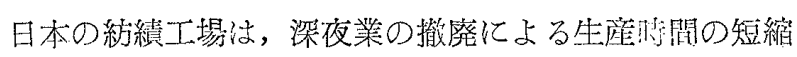
が日本の紡績生産を根本的に制約し，その生䧹虔減退さ せ，生産コス卜增大させることによって，䋓績経営に

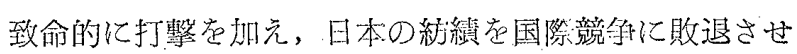
るものとみてとったのは当然のととである。日本の紡績

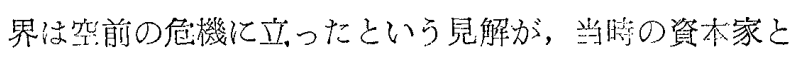

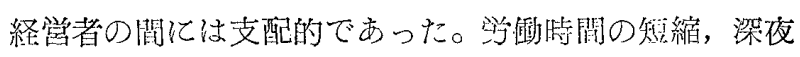
業の廃此，24特間運転の撤廃という非学事態の発展は期 せずして日本の各紡績会社祀して，その対策の街立に異 常な緊張と努力と范綕集させだ。紡績隐総力芫あげて， 短時間操業に対処するため, 研究化立ちあがった。

かよう尔情丟のなかで, 紡績技術者の生産の確保, 維 持についての努力と精進とは実にすばらしい熱意とエネ ルギーとに湍ちていたととを，とては私恃特籍したいと 思う。彼等乙そは実に深夜業撤虚, 学働時間短縮, いわ ゆる紀績の危機に対処するための対策雅立、の中核的な働 らきをした立役者であったのだ。しの立役者一一紡績技 術者は「技術て气人間を救う」ものだということを痛感 したに相違ない。

それでは，その彼等の提出した対策は何であったか。 彼等はまず紡續の生産過程，乙とにその技術的過程を， その最初の「混綿」から，紀糸の仕上げまで，また織布 の準碏工程から, 最後の仕上げ, 荷造り工程までの全部

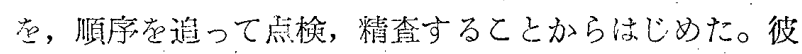
等の目的结生産のための㭙間が往来の 24 㭙問加ら 16 時

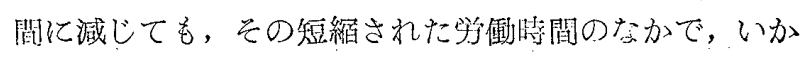

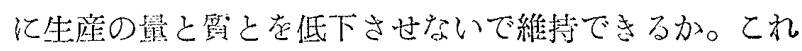


は資本主義生産の至上の目標であったととは当然であ る。12時間学憉, 徽夜業が撤廃されるのだから, 女工の 労儌条件结画期的に改善される。そして，もしてれに付 随して, 生産量が維持できれば, 学偟䍹金も向上するに

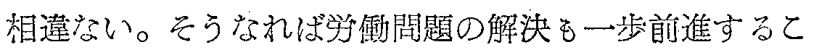
とができるであらうというのだ。実際において，ての当 時の工場はなにか殺気だっていた。技術者の㲘命な努力 が工場の空気に反映して，工場は緊張していた。私はて の情勢に気付き，浮働者にも一種のきわめて不安な気持 ちがただるっているとと斎して，每日のように工埸内 に入って，学㗢状臆に注意在急らなかった。おどろいた ことには，先の当時，工場の様子が日でとにグングン变 化していったてとだ。4,5日も巡視しないでいると，職 場の様子一とくに生産工程, 学働の仕方, 作業方式が 一変していたのだ。それ峙全くみちがえるように変って いた。技術的変革があちらにもてちらにも，あたかも競 争のような形でおてり続ける。妆工達もこの工場の雲团 気のなかで，なにか新らしい事態を感じていたようだ。 彼女らを活気づいていた。キャりャー・システムの名の 下に，夏季の紡績工場の冷房がはじまったのも，ての封 代であるととに注目したい。除塺活㗢が組織づけられ，

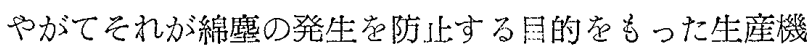
械が造り出される重要な期因となったととも，ててで注 意しよう。このようにして日本の紡績工場を吹きまくっ た変革はたしかに改㯖ではない。改良，改善という言薯

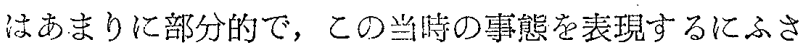
わしくない。それは革新というべき性贒のものであっ た。

ゴミゴミした混綿場がみちが光るほど清潔になったの もこの㭙である。とてでの作業の不正確や不適正が，紡 糸作業の全工程の順調な進行の障害になることが，あら ためて確㤎されたからだ。カードの工程にも徹底的な改 変があらわれた。最も注目すべさすばらしい技術的変革 は粗紡工程にあらわれた。粗紡の玉は一及計箸された。

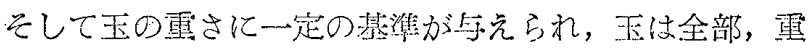
量において坛一が保持されるように改妨られた。

ての技術採用の結果は実にすばらしかった。徒来䖪粗 紵工は就業時閔中，あち引に歩き，てちらに走りるどっ

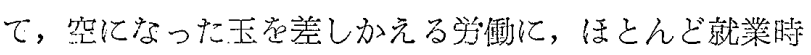
閒中卷費やしていた。もし，ちよっとした不注意老して いると，機概は空転する。代から女道はたえず空玉に 注意を向け，玉が党に娃力を集中していなくてはならな

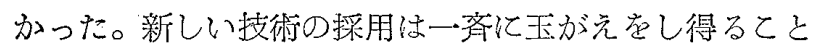

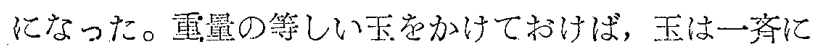

巻きとり学游じめ，一斉に巻きとりを終るから，作業は 仕易くなり, 女工達は従来のように就業時間中, 注意を 緊張させて，玉見まるる必要るなければ，た觉ず歩き まわって，カラになった㲴を取りかえるてとに忙しく立 ち㗢くというようなととは全然といってもよいほどに無 くなった。女工手灌は作業時間の中に䦥㜊を発見し, 緊

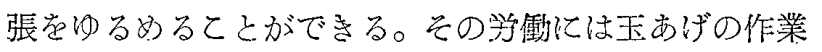
の時問と機械の看視管理の時間とがはっきりと区分さ

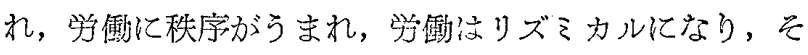

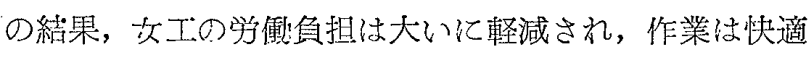
になった。

そして女工手はててでは以前よりも能衝的になりよ き生産の看視者，工程のよき管理者として，すなわち一 層に人間性に立つ学俔者となり得たのだ。そしててのよ うな污㗢条件と作業環境の下で法, 彼女等の学衝は自主

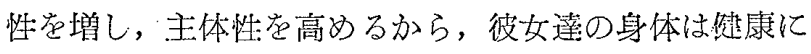
なり，その精神江活力的, 能動的と学引ざる索得ない。

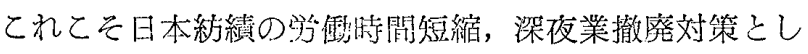
ての対策成功の笲態であっのだ。しかもてのような技 術的変革拄全紬績技術過程におてったのだからすぼらし いととである。事実この生産の技術的変革, そてに打ち 立てられた技術的秋序と規律との発見とこの原則の実行 普及とは, 日本紡績の経済的危機を打開し, 学働者の解

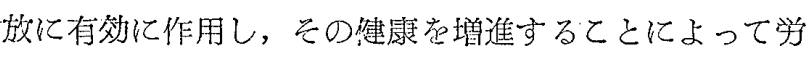

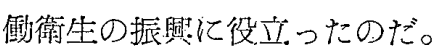

之れ以後, 私岎㗢衛生の普及之徽底によって, 学㗢 者の健康を護り, 労傎力の維持向上をはかるために统， われわれは生産技術家との㺟偅なくして注目的学達し得

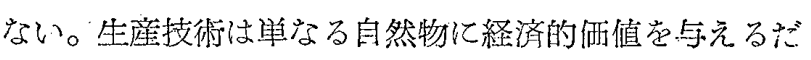

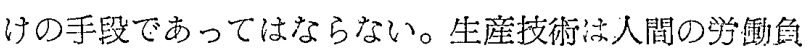
担を軽め，人間の学働の苦痛を排除し，人間を機械の制 約から解放し，自由势人間たらしめる。生産技術注人間 として，自的な学衔者として社会のなか珄きてゆくた

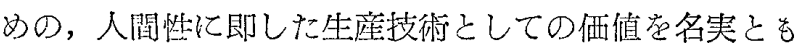
に備うべきである。るし生産技術がただ自然物保洒值

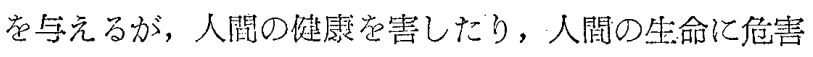
在与えたりするものであるならば，えの技術结，かつて ゲーテが，また近くはレーニンがいった如く，波して人 閵荧活かし，人生学救うものではあり得ない。

かかる見解にたって, 私站等㗢衛生の專門家々生産技 術者とがつ补に，之の泇働の共通の作業場である工場内 において, 緊密な連絡学保ち, たがいに相扶けて, とも すれば自然物の経済的何值づけのためにのみつかわれ れ，人間を苦しめてきた生産技術の誤用を防ぎとめ，他 


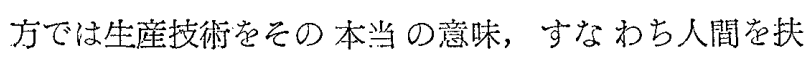
け, 人間の学働点軽減し, 人間の生命機序の発展のため 亿役立つ生産技術に鉡植し，変鞍するために妢力すべき であるという主張の上に立ってきたのである。

私はすてし横道に入ったが，本諭にかえろう。

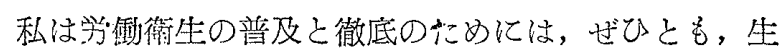

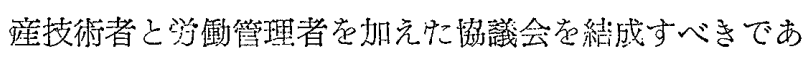
るというのが，私の堅い信念であった。前者は生産工程

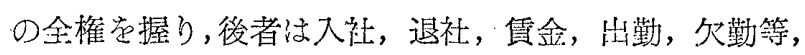
学衔条件の現実の諸事項を取扱っている。だから生産技 術者と学務管理者とを混じえて学衔街生——学衝者の煡

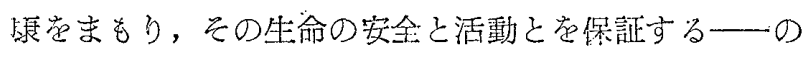
普及と徹底とについての媳談し, 討議するととが最善の 方法であるに相違ない。そてで私柱意を決して，日本産 業衛生拗議会を昭和 4 年に倉敷癸研に招請するにあたっ て，ての方針宣言して，ひろく，てれらの專門的職員 の参加赏求邓た。てれは学会ではない。あくまでも産業 の進歩のための基本的要件としての学倠者の健康と安全 そついての具体的手段を蛣議, 前進させるための会議で

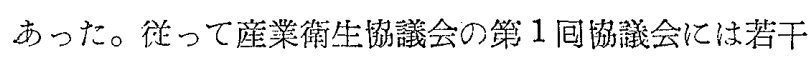
の技術者, 労務管理担当者の協力と参加と范得たのであ る。ての事は非常に雪要なととである。

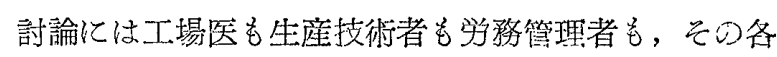
アの立場から㷛心に参加した。そしてその会場の空気は 実にヒユーマニテーに一貫していたといってよい。工場

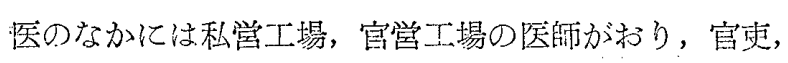
工場監督官るいたのである。産業衛生㑔議会はかくし て発足したのであるが，その後同協議会の発逘のあと走

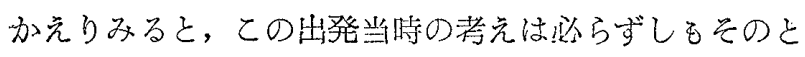

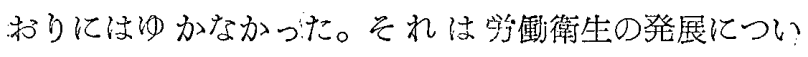
$\tau$, 次第に医学, 医術の專門的知識に立って, 専門の立 場から, 研究し, 討議される选要のある問題が多くな り, かつ他方, 学的䀧味が強く社会情勢の急变に刺激さ

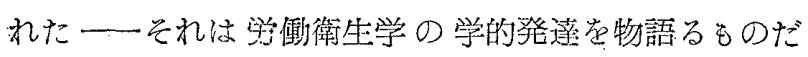
一ために，われわれの重要な饬力者であるべき生産技 術者や学駇管理者が, この学的㥸味と討議とのラデ外に 去り，彼等の発焉の機会を失わせ医学の專門家だけによ る，算門的な研究の発表と討諭とが主体と穴ったという 事実に関通している。科学の発涚による科学の分化主義 が産業衛生拹議会の綜合的協議の成立之発展と克阻んだ のである。ての事実流なほ，学衔衛生の分野におてっ た事実ではをく，今日の科学技術のすべての分野にみら れる普掘的な事実で，同時に科学発嚾の史的過程の一つ の需要な專実である。
ととに日本産業衛生協会が，その協会の一つの重要な 任務として日本産業医学会㮩年 1 回開催するという規

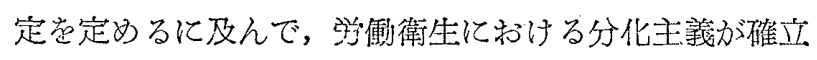
された。ての倾向に拍車をかけたのは日支雪変の勃発で ある。日本の全産業が急速汇戦争目的のために動員され るに及んで, 工場, 事業場の衛生や想康管理の仕事が著 るしく堌加した。关れ性有というものは资本上りも，

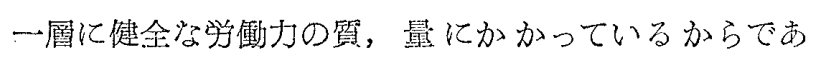

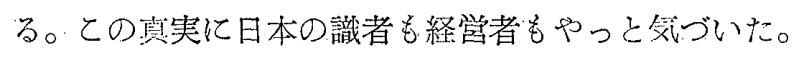

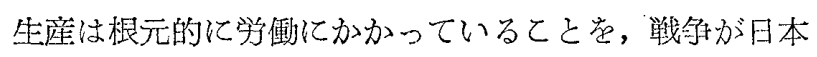

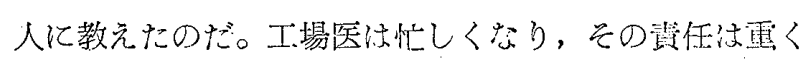
なった。

他方, 終戦後, 多くの単科大学——医科大学少澵設さ れ, 工場の衛生を專攻する研究者が数多く出現するに及

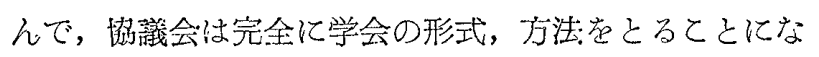
り，乙てに完全に生産技術者並びに労務管理者との拹 力, 協動の総合的な討議㹥中絶され, 上り広筑な, しか

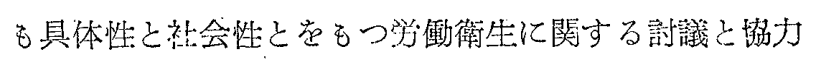
の場が失われるととになったととは，まととに遗憾なと とである。てれは科学発孉の過程の一つの現象であった とはいうものの，まてとに遺憾である。私はこの事態を みて，なにかうつべき手がなくてはらないと，命日で

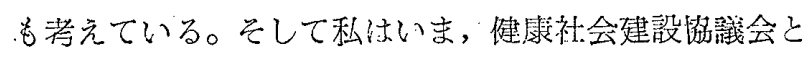
いう同志的な集団によって, その拹力的活動によって, ての方面への進展の機会をとらえようと妱力しているの である。

（註）僬康社会建設拹会はその重要な事業として，1）健

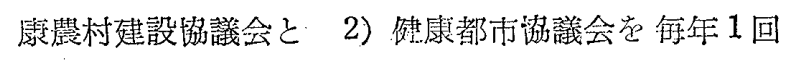
開催する。てれら二つの協議会は各及邀当恣資料を提 出し得万都市または農村自治体の現地で開催される。 との現実の資料を中心として，参会者が各及曹閇の立 場から，あるいは自己の資料と此䡴しつつ討諭するの だから，討諭は生きている。参集者は現地の保健医療 の担当者, 自治体の管理者, 教育者, 市町村長, 県知 事と保健医療技術官，乙れ飞医師会員，琵業団体，生

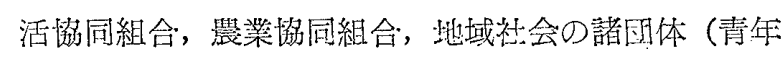
団，桪人会，等)，大学教授 (臨床及び基磼科学) 病院

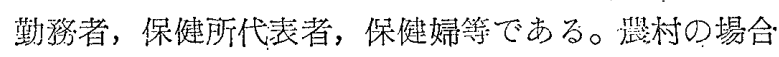
には㟽林省，地方農業関係者が出原する。そして都市 民や震村民の「生活と等徽」に関する現実の資料につ いて討緌が行われる。そしててのような社会的連紧の

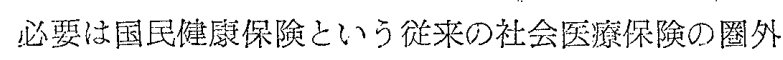
に放置された二千万の大群の民衆の社会保陾への紋集 
参亦か洼:命に強制されるといら現段階において益々重 大性を增したのである。

日本产業衛生協会の発足当時における上記のような動 间は，今日でも，さらに一首に重要であると恩う。例え ばわれわれか現下の恎大闁題としてとりあげている珪肺 の問題にしても，それは完全に新らた都市生活一大群 の家内工業者と大群の家内工業群在基盤として成立して いる日本工本の資本組繊, 従がってはその生産の諸条

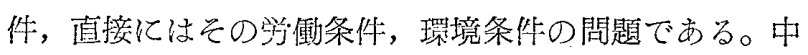
表の彰断と予防とはたしかに医学——学徽衛生の問題で あるが, 珪肺の発生やその防止はもはや一つの限定され た私企業, 私経営の問題では忘い。それは私企業, 私経 営がその属している社会に雷大な目担損畫を与光つづけ ているといら意味において，一嘼画大なのである。

最近，東京都におこっているベンゾール中毒問題も， その性貿においては同様である。徒がっててれらの被害 や中毒に刘する対策は医学や衛生学だけでは有效に進展 しない。るちろんわれわれ䅅肺発生の根本的要因虎つ きとめ秋ばならい。がしかし，一首緊急な問題は発生 の防止についての䈯正な方法の契雄である。具体的に法

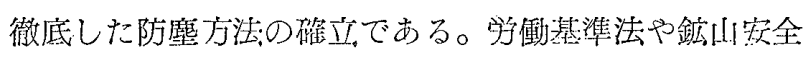
瞡則ではなま欢るい。法律は垔避的原則であり，注的強 制は管に一般的原則に止まっているという瑟由で, 現実

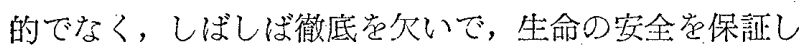
得炡い。

今日われわれに確認されている事奏は, 粉應やベンゾ 一ルの発生しないところに，珪嘲も中毒多発生はみられ

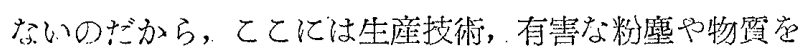
発生せしめる生産技術乙そ, 社会的負担の增大之生命と 健康を破壊する最も重要な要因でなくてはならない。有 害物の発生虎，その発生の現場で完全にとらえ，てれ觉 完全に排除してしまら技術の創造によって，珠肺の発生 徹底的に制王するとととそ，その防止の最最の手段で あるとと老承認しない人1人もないはずである。こう

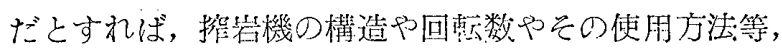
粉塺の筫と量とともに，その性状や粉塺への曝露時間の 長:さ等在制約している要件は，もちろん適切で徽底的な 排塺技術，除麼技術，空気清浄のための撸気技術の完成 こそ，珪脚の予防や防遏のための重要々要件であるし， 鳘岩機の邀用される鉣物の性筫もまた，医学者の重要な 関心事であるととはもちろんである。ベンゾールにかわ

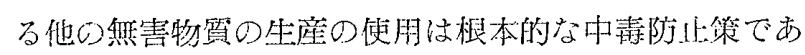
り,ベンゾールの蒸発やその漏れ完完全に制压し得る生 产应法の技術的解決とえ，最も宏全な手段である。こて

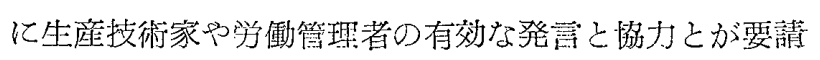
されるのは当然のてとである。

またすでに発生した坑内の有害な粉鷹やガスは徹底 的に排除されねばならないのだから，ててには作業場内 の空気の清浄方法, すなわち作業場の通気の量や，その

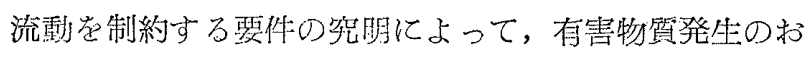

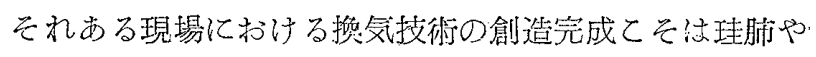
中毒防止の最隹雷要な，そして拔本的な手段であるとい ら理明によって，乙れら技術家学祳成し，現存の技術者 定その防止に有效に協力存させる必要のあるととはいう までもない。ただ医学研究者でけ集めて, 猃断, 治療 齿するだけでは対策にならない。

しかるに，かか国の現状においては，珪肪の発生やべ ンゾール中青の発生防止の急務が，今日ほど瓦係者の雷 大な関心事となっている時はないにもかかわらず，てれ ら医学者は生滻技術からの援助と協力度外視がちであ るのではないか。また生座機碱の專門家行具剣に，生座 技術が労働者に与光た被害について，てれを除去するた めの責任をどう考え，どうてれに対処しようとするの か。この社会的負担と損失とについて, 誰が珼任虏偩つ ているのか，はなはだ䁌它欠いでいる。大切なとと は, 被害者への経済的な補償ではない。補償をし, 裸價 にたよらなくては生活在維持し得ないよらな人間存1人 です出さないという，健全で吱全な生産技術の普及徽底 とそ䜿急な問題なのだ。

\section{IV 技術における人間性の失落とその恢復}

当働衛生——般には学衝保謢についての今日のよう なセクショナリズムの扟る原因として，科学及び技術 におけるヒューマニダーの久去を指摘したいと思う。欧 米の先進国においては,ルネッサンス以来, 相つづいて おてりつづけた主的革命の大きな波濤のなかで, 資本 主義経洨の不断の発展のなかに就てすら, その社会に 生れた科学技術や生产技術の中核には賞にヒユーマニチ 一がー買して流れていたてとに注意を回ける必要があろ う。勃䯠発達する科学と技術とは，たえずヒユーマニチ 一から一一あるは科学以前の中世紀潒通じて伝承され， てきたクリスチアニチーからといってもよい一一の強い 批判虑うけとり，乙の新らしい生産技術といら槐術江た えず，その反人聞性に対するきびしい反省が琵請されて きた。すなう技術は人間を生かし，人䦎虎して人間た らしめる人間完成の手段であるとは，西欧社会り基底を なしている文化的伝統であると私は考える。技術におけ

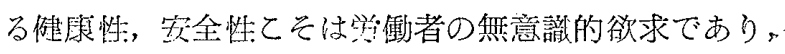


また，关れは人間幽の自覚においての切实示要求とし て，労働組合活動の最む重要な目標である。これ仿かっ てデカルトの哲学, ゲーテの芸術, そして近くはレーニ ンやマルクスの労働観，経済観の雷要な要素とにつなが っている。ヒユーマニチーて六沽技術一生産技術の本 貿的な洒值とその文化的使命の決定者であら㸚ばならな い。乙の意味において, 生产技術法断じて資本主義経済

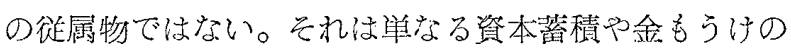
手段ではなく, 人間—学働者の人間的完成とその生命 の尊基のための，佂值高き支化的，社会的資産であらな ばならない。

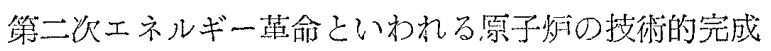
への過程におろて, 英米り連などの先進国の科学技術者 のとった態度に注目守る人低, 彼等の新技術創造の仕事

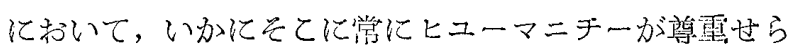

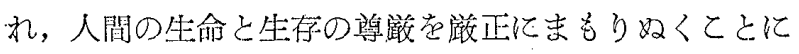
妢力しているかに注意したに相違ない。乙れら諸国の技

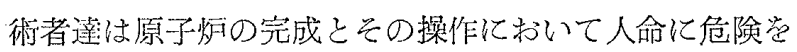

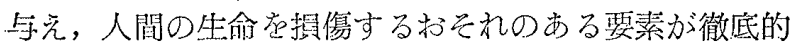
に排除されない限り，公の技術の採用を拒否し続けたで はないか，号れは陌欧の科学と技術が，乙の函期的な新 技術の社会的採用に打引る彼等の技術的精神の步らわ れであると私蛙考党る。一だがての技術的精神怯，一 旦，原子力の利用が国際的紛争の粠利者であらうとする

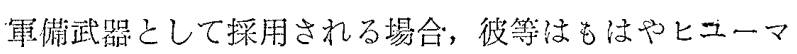
ニストたる資格と伝統之在捨て去らざるを得なか力たと いら事実は，まさしく彼等の伝統的技術精神の放寨在意

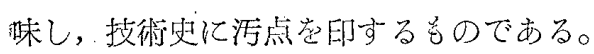

日本纺科学上技術との多くのもの西欧から受取った のである。ぞが科学や技術の日本への導入にあたって， 日本はこれを窝国強兵の手段とし，日本資本主黪の発展 のた少には不可欠の手段として洒値ありと認める限りと

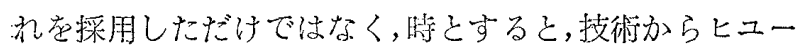

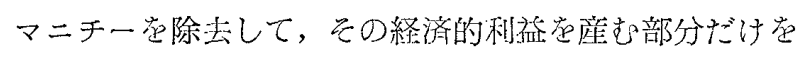
採用するといら暴挙すらあえて害行したのである。経済 的利益のためには人間の尊需に煩かぶりし，人間の生命 堂犠牲にして，專ら生産のた勿にてれ棌用するという

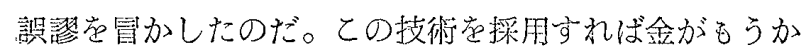
る。経紊競争に勝てる。これとこ日本資本主義発展の過 程における生产技術適用の姿であったのだ。従って日本 の技術教育に㧈いて，同様にまた日本の科学教育の過程 の中では，技術はヒユーマニテー老見失ってきたのだ。 日本の技術家一医即古含めて一ーはヒニーマニチー の视い，単なる自然物の加工，自然物の経消的価值づ
け，医術では人間といら生命機珹の修綪の手段としての 技術を身付るだけの人間となり，日本産業と元の生 産技術とは過去半世紀にわたって，兑の西欧からの移入 の時代汃ら今日に至るまで，加ような「技術的精視のぬ けた」「金るうけの技術」，資本に隷属劣る技術としての ぬ役立てられてきたといっても過言では心い。

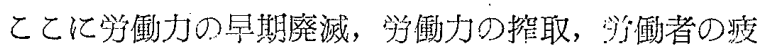
学—過等, そして, 不健廉, 病気, 遂には職場切引 る重大な㷋管の発生，全面的な学衝不实，社会不宛の原 因と，そのた壳ざる発展という不幸がおてりつづけた最 大の原因があると私は考学る。

私は今ててに誈を大にして「科学と技術とにヒユーマ ニチーを取りもどそうで洁ない加しいいたい。われわ れが現在及び将来の社会に必要とするもの结筆に「物に 価值を与える」生産技術であって称学引ない。産業の园

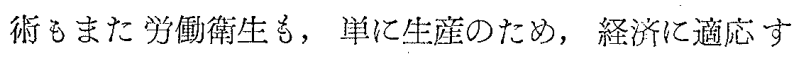
る，いかえると経消的利搵を特牲にしない筑围内だけ の学衔力—人間の保護の技術であってはならない。こ れはわれわれの技術でない。真に学働する人閔の生命の 尊㛜のための技術ではない。われわれの生産技術住徹頭

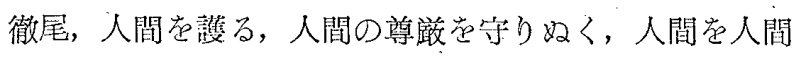
たらしめるとと，人間を菜痛から解放し，人間起㓣造 的, 能動的な学㗢者たらしめるととに有效に作用すると ころの生産技術である。

幸いなととにも，終戦後の民主主羡への国民的前進に よって, また他方では学働基準法关の他関係諸法令の実 施によって，生産技術におけるヒユーマニテ一一人間 性はやっとわが生産機棈のなかによみがえり, 技術教育

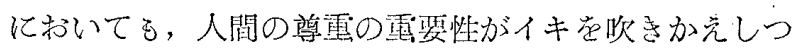
つある。乙の事実活将来の学衝衛生の研究とその実践と

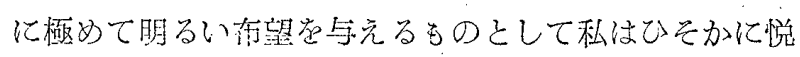
んでいる次第である。この意味において第二次世界大戦 後の日本はまさしく「産業注け引る人間性の目ざめ」の 㭙機党迎えたのだというべきだろう。それ法東海村の原 子炋の科学技術者洷の原子力開発のための仕事における 慎雷な態度に昭確に表徽されていることで悦ばしい限り である。

かくしてわれわれはやっとわれわれの一学衙衛生の 進歩への社会的責任者の任務—いかなる事情があるう と，われわれは学働者の䛧康在守り，学働者の病気を治 療し, 䂆防するてとによって, 社会的生産の问上発橽に 简与し, 己って学樹者個々人之社会的福祉と繁栄のため に晐働するという任務をより完全に果たすてとのでるる 希望々悦びをもち得る段階侄到りつつあると思う。 


\section{V 展望一工工場医会を結成せよ}

最後に工場医問題について一言するとと学許るしても らいたい。それは産業衛生劦会という絽織の改革につな がる問題である。産業衛生茄会は産業医学会に塺苍ゆず る時期がきたのだ。産業衛生協会の組織のなかで荅って また産業医学会は成年期に達したのだ。産業衛生茄会と いら母:手在は心れて, 産業衛生学の専闍研究者, 大学 の教職にある人たちの独自の学会として, 独自の発居を 期すべきである。それ国際的にも必要で適切かつ緊急 な手段である。

それでは産業街生塌会はどうなるか。

打樹省当局の発表によると，日本には現在，約 2,000

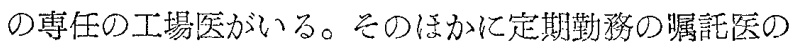
数は約 4,000に上るといわれている。このうち臂任工場 医の大部分は産業衙生㩲会真であると㨦定される。しか るに工場医は終戦後, 学働法規の確立に從がって, その 社会的職能とその地位。る非常に舆大になってきたとと は周知のとおりだ。彼の診断は労働時間の堅漳定決定す る要件となる。彼は健康状態の如何によって，等衝者に 休養を治療手段として俞ずることが可能である。彼は学 㗢者の採用や退職について露要な役㓶定むっている。紋

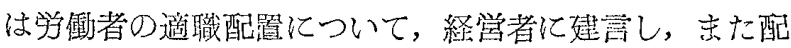
置転撸の必要起決定する重要な因子を握っている。彼は

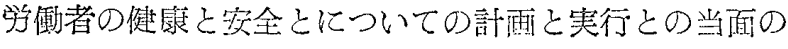
責任者であり，かつ実践の，また，その管理の主体者で ある。彼は職業性深㭧の決定者であり，その防止の珼任 者である。

彼はまた，学働者と経営者の双方に，学働環境の改善， 作業条件の最良化をつ放具体的に示晙することによっ て，生産性の向上に笴与する任務起むた称ばならない。

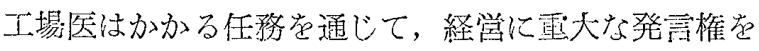
もち，経学計画に参与虽べ地位にいるのである。工場 医の経営内における任務はますます重大焅孝增してく る。経営が発展するほど, 生産の技術が高度化し, 経営 間の競争方゙はげしくなるはど，工場医の任務は董大化

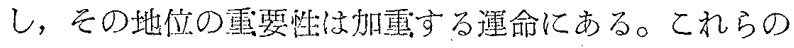
点では工韵医は学衝衛生の専門の研究者や大学の教授た ちと, 職责党はなはだ異にしている。後者は経営に対 し, 労働者に対して指示榷も発焉整もるっていな!。し かるに前者はその職分は経営に関与し，㢈業学働法令に 責任苯もっている。その意味でも, 工場医会の維成が必 要だといらのである。

他方，以下のような褁任工場医の身分と職責とは，経
営者と学働組合とから完全に独立した立場が綮としてま もられねばならない性筫のものである。科学的見解に立 ち, 科学の提出する宾実の上に立って, 専任工場医は学 資の約等に公正なる資料党提出し，その正しい解決を導 びさ出す任務を层う機会は，今後，一層多くなるに相違 ない。

しかるに，ただ貴任が扣霣されるだけで，工場医には なんら法的な保護も職権尊重についての法的基礎も与元 られていないではないか。私け弚働基準法は工場医の職 责をないがしろにし，工場医虎ふみにじっているとさ光 いらのである。

とのような情勢の中において，私はわが日本に，いま や「工場医」の組織とその活動がおてらねばならない時 期少きているとみるのである。イギリスには Factory Doctorの組織汃確立さされているし，ドイツには Werkarztが経営内に重要な地位定占わている。その他の国飞 にもまた，尃任工場医がて，それらの専任工場医はそ れぞれの独兒の組織と䋧織活動芷もっている。

さらに雷要なととは，專任工場医の地位や待遇や冁酬 に関しては，それぞれの国はその工場医組織と経営者団 体との閆の四体交涉によって，大ワクが決定され，その 待遇，その地位の決定や昇給，退職手当等に関しては， その団体交涉によって決定された大ワクの䉇田内，また 壮それ基集として決定されるといらとてろまで組織活 動が及んでいる。医師は特别待遇者であるという見解 が, 日本の経営者や学働組合の中に, 普遍的に普及して いる現状は，專任工場葍にとって不圭なととである。

專任工場医は福利厚生という，生産的でない事業部面 の担当者である。そうした職分として評価されるといら 考光方は正当でない。尃任工場医は経営の三大要件一一 すなわち, 資本, 施設, 人䦰 (労働力) という三つの要 件のうち，最も重要な人閐という要件についての科学的 技術者である。彼の技術の経営への邀切なる採用は経営 の発展にとっての熏大琵件である。尌任工場医のもって いる技術は，それが人間の科学であるとの理由によっ て，まさしく生産的技術なのである。等なる厚生一一す なわち医療の技術ではない。工場医の地位と処遇とは向 上さるべきであり，また専任工場医けその地位の向上に 価する独自の生座的技術を発展させ，工場医の緝集によ

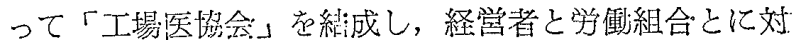
して，政正な中立的地位在確立することによって，その 経栄内に㧍ける地位と処遇とも確立すの゙きである。

上上の理由によって，一方では日本産業医学会の独主。

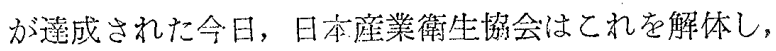


あらたに工場医垛会を專任工場医の団体として発足させ るととが，日本産業の発展に即応する㢣要な手段である と，私蜼信している。4,000 名に上る定時制工場医や嘱 託医は準会員とし，ててから有能な正会員としての專任 工場医ができてよいで岕いか。

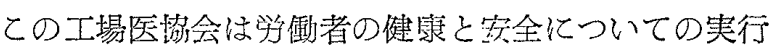
者, 管理者としての権限をもつ雷要子専門技術者の団体 である。てれは学衔者の支配から完全に独立した性格を

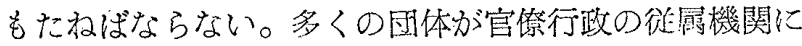
なる傾向のあるわが国において，てのとと纹特警牫さ

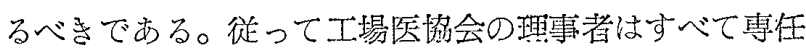
工場医のなかから䢩出され，自由な專門家の集団とし て，关の科学的知見と経倹とに基いて，わが国の学衔衛 生の発展のために，つ㸚に主体的にかつ自由に，現寒に

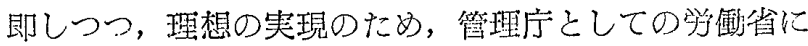
協力する団体となるとと老切に期待するものである。

(49頁より綕く)

終戦後, 九州地方在住会貣有志を中心として, しばし ば会合方持たれ，㙐方産業衛生の指導等，地方会活動が 行なわれてきたが，昭和22年11月15日，福㒺市九大医学 部衛生学教室において総会汃開唯され, 地方会規約の制 定起み，三井産研所長石西進氏か法方会長に選任された。

昭和23年 11 月 9 日九大教授水島治夫氏が第 2 代地方会 長に選任され，今日に至つている。地方会正式成立以来， 地方会活動は組織的に行なわれ，次の規約改正手行なう そともに，每年 2 回総会及び研究会苍開き，今日に至つ ている。会貝数も炤和 23 年 2 月, 111 名であつたが，昭 和 27 年 9 月には 176 名, 昭和 34 年 8 月, 233 名之順調に 発展している。

\section{2. 主要行事}

昭和 22 年 11 月より今日までにおいて地方会で行なつ た主要行事はつぎのとおりである。

(1) 総会及び研究会：21回開催され, 発表された演題 349 題. 特別講演 21 回, シンポジアム 11 回が行なわ れだ。

（2）日本産業医学会の開催：细和27年 3 月福岡におい て地方会担当にて開催された。

（3）衛生管理者講習会：昭和23年と25年の 2 回，地方 会主催にて開摧された。

（4）印刷物：研究発表抄録集 6 冊, 特別講演要旨 7 冊 を発行した。

産業衛生睈会九州地方会主要行事歴年表

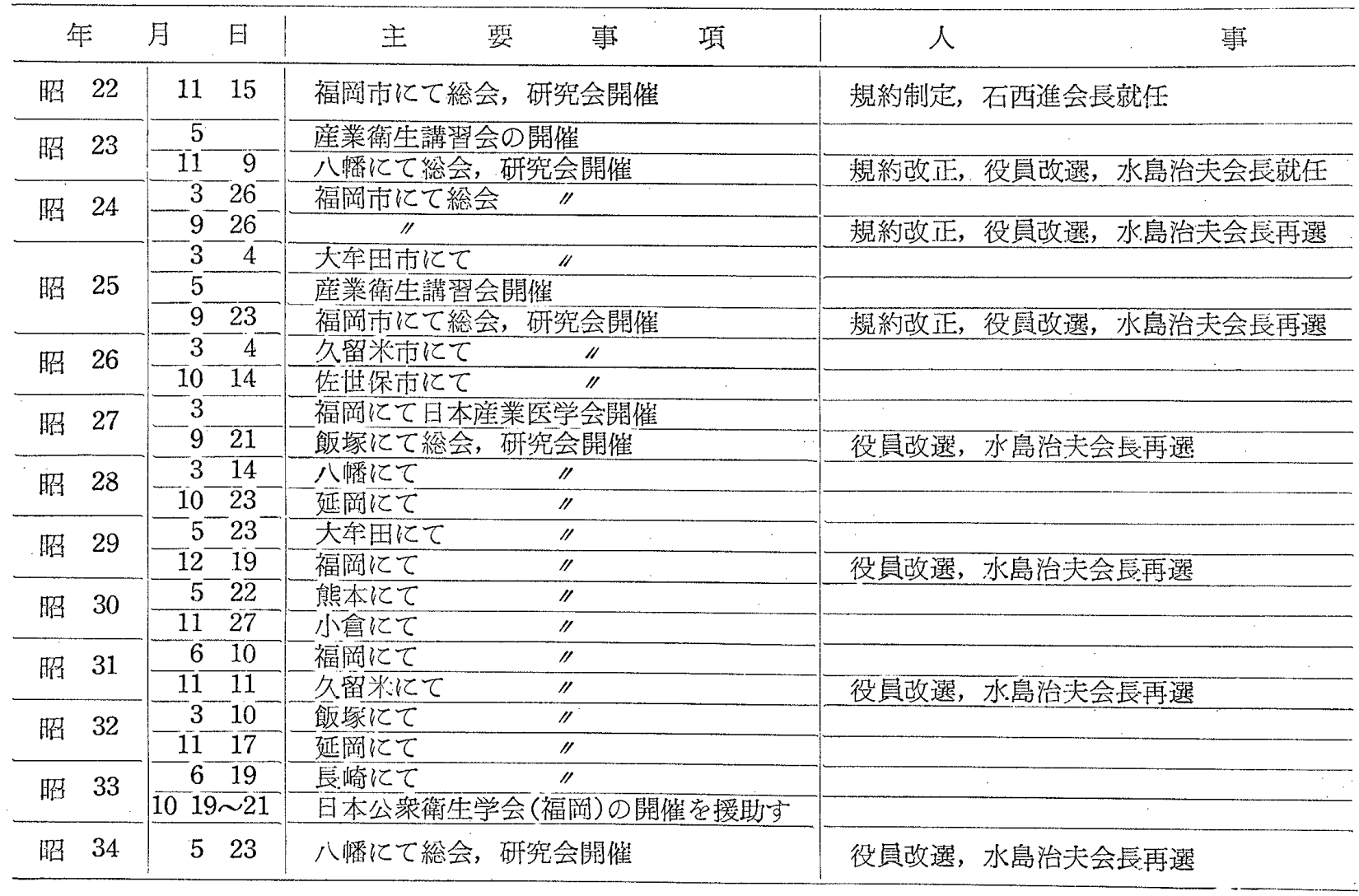

